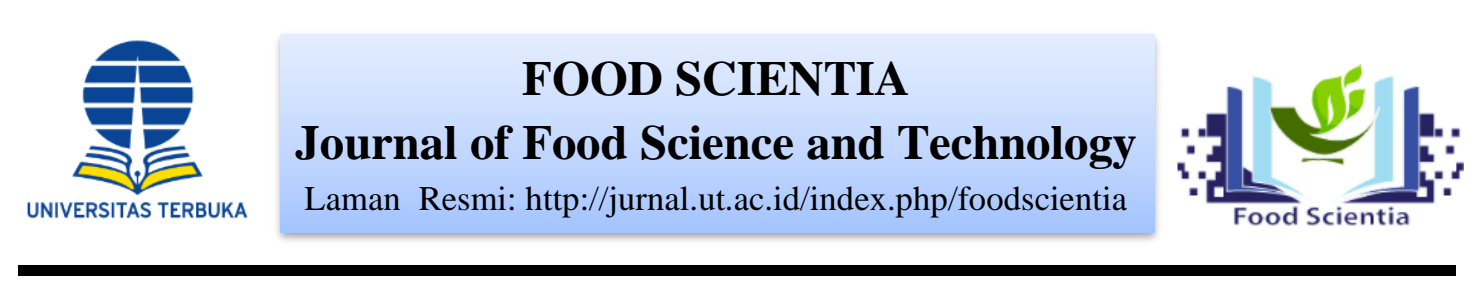

KAJIAN PEMANFAATAN SUSU NABATI SEBAGAI PENGGANTI SUSU HEWANI

\title{
Review of Plant-Based Milk Utilization as a Substitute for Animal Milk
}

\author{
Intan Maris ${ }^{1}$, Mohamad Rajih Radiansyah ${ }^{2}$ \\ 1,2 Program Studi Teknologi Pangan Universitas Terbuka \\ Jalan Pondok Cabe Raya, Tangerang Selatan, 15148, Indonesia \\ e-mail: intan.maris@gmail.com
}

DOI: $10.33830 /$ fsj.v1i2.2064.2021

Diterima: 12 Sep 2021, Diperbaiki: 15 Okt 2021, Disetujui: 22 Des 2021

\begin{abstract}
In general, milk is a white liquid secreted by animal's mammary gland and contained lactose. Problems occured when some people have an allergy to lactose thus an alternative is created in the form of dairy products with plants as the basic ingredient. This study aims to determine the nutritional value and the advantage of plant-based milk on health and nutrition fulfillment so it can be used as a substitute of animal milk for people with lactose intolerance. In this study, the milk in plant-based milk refers to extracts of various plants. Plant-based milk has a distinctive odor depending on the plant-based ingredients used. In this article, the study was carried on the physical characteristics, nutritional values and benefits of plant-based milk consumption for health and a comparison with animal milk (cow's milk) was also done. The literature indicated that nutritional value of plant-based milk is comparable to animal milk. Despite no observable physical differences between plant-based milk and animal milk, there was still a need for improvements in the way to add flavour to plant-based milk to attract consumer's interest. Plant-based milk has its benefits for heart health due to its lack of cholesterol levels in it. There are five types of plant-based milk studied within the scope of this article; these are soy, almond, oat, mung beans, and cashew.
\end{abstract}

Keywords: Plant-based milk, Alternative food, Food technology

\begin{abstract}
ABSTRAK
Pada umumnya susu merupakan cairan berwarna putih hasil sekresi kelenjar mamae yang berasal dari hewan dan memiliki kandungan laktosa. Permasalahan terjadi ketika beberapa orang memiliki alergi terhadap laktosa sehingga terciptalah alternatif berupa diversifikasi olahan susu dengan menggunakan tanaman sebagai bahan dasar. Studi ini bertujuan untuk mengetahui seberapa besar nilai gizi dan manfaat susu nabati terhadap kesehatan dan pemenuhan gizi sehingga dapat digunakan sebagai subtitusi susu hewani bagi penderita lactose intolerance. Susu nabati yang dimaksud adalah sari dari berbagai sumber tanaman.
\end{abstract}


Susu nabati memiliki bau yang khas tergantung bahan dasar tanaman yang digunakan. Dalam artikel ini dilakukan tinjauan studi mengenai karakteristik fisik, nilai gizi serta manfaat dalam mengkonsumsi susu nabati bagi kesehatan dan dilakukan perbandingan terhadap susu hewani (susu sapi). Hasil literatur menunjukkan bahwa nilai gizi yang didapat dari susu nabati tidak berbeda jauh dengan nilai gizi susu hewani. Meskipun secara fisik tidak ada perbedaan antara susu nabati dan susu hewani, namun masih perlu dilakukan pengembangan dalam penambahan cita rasa pada susu nabati untuk menarik minat konsumen. Mayoritas susu nabati bermanfaat bagi kesehatan jantung karena minimnya kadar kolesterol di dalamnya. Terdapat lima jenis susu nabati yang dikaji dalam studi ini yaitu yang berasal dari kedelai, almond, gandum, kacang hijau, dan kacang mete.

Kata Kunci : Susu nabati, Pangan alternatif, Teknologi pangan.

\section{PENDAHULUAN}

Susu merupakan produk pangan alami yang banyak dikonsumsi dari segala usia. Susu merupakan produk pangan alami yang sangat kaya akan zat gizi yang esensial bagi pertumbuhan dan perkembangan tubuh manusia (Winarno, 2016). Umumnya, susu yang dikonsumsi manusia berasal hewan ternak seperti kambing, kerbau, unta, dan hewan ternak lainnya, namun susu sapi adalah susu hewani yang lebih sering dikonsumsi oleh manusia. Nilai gizi pada susu sapi rata-rata memiliki kandungan air sebanyak $84-90 \%$, bahan padat $10-16 \%$, lemak 2,60-6,00\%, protein 2,80-4,00\%, laktosa 4,50-5,20\%, dan mineral sebanyak 0,60-0,80\% (Muchtadi, 2019).

Dalam susu hewani terdapat kandungan laktosa atau gula susu yang merupakan komponen gula penting. Kegunaannya dapat membantu asimilasi kalsium dan fosfor sehingga membentuk tulang dan gizi yang lebih baik dalam tubuh (Muchtadi, 2019). Namun ada beberapa individu yang mengalami lactose intolerance yang disebabkan oleh laktosa dalam produk susu kemudian terjadinya defisiensi laktase dan memicu reaksi seperti nyeri perut dan distensi, borborygmi, dan diare (Deng et al., 2015). Di seluruh dunia, 70\% dari populasi orang dewasa memiliki ekspresi enzim laktase yang terbatas dengan variasi yang luas, baik disebabkan karena malabsorpsi laktosa maupun intoleransi terhadap laktosa yang berasal dari dalam produk susu di berbagai wilayah dan negara (Facioni et al., 2020). Maka dari itu, diperlukan solusi alternatif bagi penderita lactose intolerance untuk tetap mendapatkan asupan gizi yang sebanding dengan kandungan gizi dalam susu sapi ataupun susu hewani lainnya.

Seiring dengan perkembangan fungsional pada bahan pangan, diketahui kini sumber susu tidak hanya berasal dari produk hewani. Bahan dasar tanaman dapat 
dikembangkan fungsinya menjadi bahan dasar pembuatan susu, umumnya masyarakat menyebutnya sebagai susu nabati. Susu nabati umunya berasal dari varietas tanaman kacang-kacangan yang diproses melalui pemanasan suhu rendah di bawah $100^{\circ} \mathrm{C}$ selama waktu tertentu (pasteurisasi). Susu nabati yang dimaksud dalam kajian ini adalah sari dari berbagai sumber tanaman. Secara fisik, susu nabati tidak memiliki perbedaan yang signifikan terhadap susu hewani. Viskositas susu nabati dan hewani hampir sebanding tergantung pada kandungan lemak di dalamnya (Sentana et al., 2017). Namun ada perbedaan dari segi warna dan rasa tergantung pada varietas tanaman yang digunakan. Susu hewani memiliki warna putih kebiruan, viskositas rendah, dan rasa manis (Muchtadi, 2019).

Susu nabati dengan cepat mendapatkan perhatian pada skala global sebagai alternatif yang memungkinkan karena kekhawatiran terkait dengan konsumsi susu terutama bagi penderita lactose intolerance (Kehinde et al., 2020). Oleh karena itu, penulisan ini bertujuan untuk mengkaji berbagai informasi terkait karakteristik fisik dan nilai gizi susu nabati dan melakukan perbandingan dengan susu hewani. Tulisan ini juga bertujuan untuk mengetahui dan mengkaji ulang besaran manfaat susu nabati sehingga layak dijadikan sebagai pengganti susu hewani bagi tubuh manusia.

Kajian ini dilakukan melalui pengambilan data sekunder dengan menggunakan data deskriptif berupa tinjauan ulang studi literatur yang mendukung pernyataan terkait karakteristik bahan dasar, kandungan, nilai gizi, dan manfaat yang diperoleh dari mengkonsumsi susu nabati. Penelitian ini mengambil beberapa varietas tanaman diantaranya kedelai (Glycine max), almond (Prunus dulcis), gandum (Triticum sp), kacang hijau (Phaseolus radiatus), dan kacang mete (Anacardium occidentale L.). Pada masing-masing tanaman tersebut akan dikaji varietas mana yang paling banyak dijadikan olahan susu dan dikonsumsi oleh masyarakat.

\section{Karakteristik Fisik dan Kimia Susu Nabati}

Susu nabati adalah susu yang berasal dari tanaman yang telah dikonsumsi selama berabad-abad tahun dalam berbagai budaya, baik sebagai minuman biasa ataupun sebagai pengganti susu. Seperti diketahui, laktosa hanya di produksi oleh kelenjar ambing, sehingga susu nabati tidak mengandung laktosa seperti susu yang berasal dari hewan (Hasanah et al., 2020). Susu nabati memiliki kandungan gizi yang 
hampir setara dengan susu hewani, dan dapat dijadikan sebagai produk pangan alternatif bagi penderita intoleran laktosa, dimana protein susu tidak dapat dipecah di dalam tubuh karena produksi enzim laktase tidak bekerja secara optimal. Susu nabati juga kaya akan vitamin dan mineral seperti vitamin $\mathrm{E}$, vitamin $\mathrm{B}$, antioksidan, fosfor, dan isoflavon (Pratita, 2012). Fokus yang diberikan oleh susu nabati yaitu kandungan protein tinggi yang diperoleh dari tumbuhan. Susu nabati merupakan susu yang dibuat dari tumbuhan terutama dari jenis kacang-kacangan dan serealia (Larosta et al, 2019). Umumnya, varietas tanaman yang sering diolah menjadi susu nabati adalah susu yang berasal dari golongan serealia dan kacang-kacangan. Masing-masing varietas memiliki karakteristik unggul yang berbeda, tergantung pada kebutuhan konsumsi manusia. Berikut perbedaan mutu sensori antara susu nabati secara umum dan susu hewani (susu sapi) yang ditampilkan pada Tabel 1. berikut.

Tabel 1. Mutu Sensori Susu Sapi dan Susu Nabati

\begin{tabular}{ccc}
\hline Mutu Sensori & Susu Sapi & Susu Nabati \\
\hline Warna & Putih kekuningan & $\begin{array}{c}\text { Putih kekuningan / kehijauan } \\
\text { (tergantung bahan dasar nabati } \\
\text { yang digunakan })\end{array}$ \\
Tekstur & Encer & Encer \\
Rasa & Manis & Tawar \\
Bau & Khas susu & Khas bahan dasar nabati \\
\hline
\end{tabular}

Berdasarkan Tabel .1 di atas, perbedaan mutu sensori antara susu nabati dan hewani tidak menunjukkan perbedaan yang signifikan. Proses pembuatan susu nabati sangat mudah dan bisa dilakukan di rumah. Pembuatan susu nabati menggunakan proses pemanasan pasteurisasi. Pasteurisasi adalah proses pemanasan dengan suhu tidak lebih dari $100^{\circ} \mathrm{C}$ selama waktu tertentu (Muhami, 
Food Scientia Journal of Food Science and Technology 1(2) 2021, 103-116

2017). Adapun perbandingan nilai gizi antara susu nabati cair dengan susu hewani (susu sapi) dapat dilihat pada Tabel 2.

Tabel 2. Nilai Gizi Susu Sapi dan Varian Susu Nabati

\begin{tabular}{|c|c|c|c|c|c|c|}
\hline Komponen & Susu Sapia & $\begin{array}{c}\text { Susu } \\
\text { Kedelai } \\
\text { Cair }^{\mathrm{a}}\end{array}$ & $\begin{array}{c}\text { Susu } \\
\text { Almond }^{b}\end{array}$ & $\begin{array}{c}\text { Susu } \\
\text { Gandume }\end{array}$ & $\begin{array}{c}\text { Susu } \\
\text { Kacang } \\
\text { Hijaud }^{\text {d }}\end{array}$ & $\begin{array}{c}\text { Susu } \\
\text { Kacang }^{\text {Mete }^{\mathrm{e}}}\end{array}$ \\
\hline Air (\%) & 88,60 & 88,60 & 86,11 & - & 87,5 & - \\
\hline Kalori (Kkal) & 58,00 & 52,99 & 55,40 & 0,17 & 0,015 & 52 \\
\hline Protein $(\%)$ & 2,90 & 4,40 & 1,70 & $2,5-5$ & 1,57 & 1,31 \\
\hline Lemak (\%) & 0,30 & 2,50 & 3,40 & $4,5-5$ & 0,17 & 3,16 \\
\hline Karbohidrat (\%) & 4,50 & 3,80 & 4,50 & $19-29$ & - & 4,74 \\
\hline Kalsium (mg) & 10 & 15 & 13,10 & - & - & 98,5 \\
\hline Fosfor (mg) & 90 & 49 & 75,20 & - & - & - \\
\hline Natrium (mg) & 16 & 2 & 6,38 & - & - & - \\
\hline Besi (mg) & 0,1 & 1,2 & 1,40 & - & - & - \\
\hline Vitamin A (\%) & 0,20 & 0,02 & - & - & - & - \\
\hline Vitamin B1 (\%) & 0,04 & 0,04 & - & - & - & - \\
\hline Vitamin B2 (\%) & 0,15 & 0,02 & - & - & - & - \\
\hline $\begin{array}{l}\text { Asam lemak } \\
\text { jenuh }(\%)\end{array}$ & $60-70$ & $40-48$ & - & - & - & 0,44 \\
\hline $\begin{array}{l}\text { Asam lemak } \\
\text { tidak jenuh }(\%)\end{array}$ & $30-40$ & $52-60$ & - & - & - & - \\
\hline Kolesterol (\%) & $9,24-9,9$ & 0 & - & - & - & 0,44 \\
\hline Abu (gram) & 0,7 & 0,5 & - & - & - & - \\
\hline
\end{tabular}

Keterangan : Satuan dalam per $100 \mathrm{~g}$

Sumber : ${ }^{\text {a. }}$ (Istiqomah, 2014); ${ }^{\text {b: }}$ (Alozie et al., 2015); c: (Gutierrez, 2020); ${ }^{\text {d. }}$

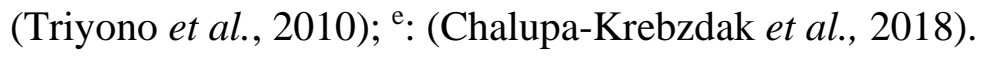

\section{Susu Kedelai}

Kedelai merupakan salah satu tanaman penting yang telah lama dibudidayakan di Indonesia. Kedelai yang termasuk dalam kategori tanaman palawija merupakan salah satu sumber protein nabati yang cukup penting karena kedelai mengandung asam amino esensial yang lengkap. 
Menurut Damayanti dan Murtini (2018), kadar protein kacang kedelai cukup tinggi yaitu 30,44\% dibandingkan dengan jenis kacang-kacangan lainnya. Kedelai yang lebih banyak digunakan untuk pengolahan susu kedelai yaitu kedelai kuning. Satu cangkir susu kedelai yang tidak difortifikasi (belum mengalami pengayaan) mengandung hampir 7 gram protein, 4 gram karbohidrat, 4,5 gram lemak dan tidak mengandung kolesterol (Aidah, 2020).

Berdasarkan Tabel 2, dalam 100 gram susu kedelai cair terdapat kadar air sebesar 88,60\%. Kandungan air dapat berubah sesuai dengan jumlah air yang ditambahkan untuk melarutkan susu kedelai, hal ini berpengaruh terhadap nilai viskositas. Semakin besar tingkat konsentrasi susu kedelai, maka nilai viskositas susu kedelai semakin besar (Istiqomah, 2014). Kemudian pada nilai kalori susu kedelai menunjukkan angka sebesar 52,99 Kkal. Kadar protein sebesar 4,40\%, lebih besar bila dibandingkan dengan kadar protein susu sapi yaitu sebesar 2,90\%. Kadar lemak susu kedelai sebesar 2,50\% kemudian kadar karbohidrat sebesar 3,80\%. Kandungan mineral yang terdapat dalam susu kedelai seperti kalsium, fosfor, natrium, besi, dan abu masing-masing adalah $15 \mathrm{mg}, 49 \mathrm{mg}, 2 \mathrm{mg}, 1,2 \mathrm{mg}$ dan 0,5 gram. Kadar vitamin yang dihasilkan adalah 0,02\% untuk vitamin A dan B2 serta 0,04\% untuk vitamin B1.

Susu kedelai adalah salah satu hasil olahan kedelai yang dihasilkan dengan cara mengekstrak protein kedelai, kemudian mengencerkannya sampai diperoleh penampakan yang mirip dengan susu sapi. Protein susu kedelai mempunyai susunan asam amino yang mirip dengan susunan asam amino susu sapi.

Susu kedelai memiliki tekstur encer cenderung kental tergantung dengan volume air yang ditambahkan, berwarna putih kekuningan, dan memiliki bau langu yang khas. Salah satu masalah yang sering muncul dalam produksi susu kedelai adalah timbulnya bau langu pada susu kedelai yang dihasilkan. Bau langu ini disebabkan oleh adanya aktivitas enzim lipoksigenasi yang secara alami terdapat dalam kacangkacangan (Aydar et al., 2020). Untuk mengatasi masalah tersebut, perendaman, pelepasan kulit, pemanasan pada suhu $100^{\circ} \mathrm{C}$ selama beberapa detik, pemberian gula dan essence atau penambahan daun sirih pada saat perebusan dapat mengurangi bau langu tersebut. 


\section{Susu Almond}

Almond merupakan jenis tumbuhan kacang-kacangan yang populer karena rasanya yang gurih, sedikit manis, dan empuk. Almond memiliki kandungan gizi yang cukup tinggi, salah satunya adalah kandungan lemak yaitu sebanyak 49,4\% dengan tingkat asam lemak tak jenuh tunggal yang tinggi sebesar 67\%, yang bermanfaat bagi kesehatan jantung (Hasanah et al., 2020). Kandungan lemak nabati yang cukup tinggi membuat almond memiliki cita rasa gurih. Selain itu, almond juga memiliki kandungan gizi lainnya yang cukup tinggi, di antaranya adalah vitamin E (25,63 mg), serat (10,7 gram), kalsium (169 mg), kalium (481 mg), dan fosfor (733 mg) dalam 100 gram almond. Konsumsi satu takaran saji almond (20-25 biji) akan menghasilkan 15 gram lemak, dan lebih dari 90\% merupakan asam lemak tidak jenuh (Damayanti \& Murtini, 2018).

Kandungan utama susu almond dalam $100 \mathrm{ml}$ terdiri dari kadar air sebesar 86,11\%, Kalori sebesar 55,40 Kkal, lemak sebesar 3,40\%, karbohidrat sebesar 4,50\%. Kelemahan dari almond yang sudah diolah menjadi susu ini adalah kandungan protein yang cukup rendah bila dibandingkan dengan susu nabati lainnya, yaitu 1,70 gram per $100 \mathrm{ml}$ (Alozie et al., 2015). Untuk itu, untuk menambahkan kadar protein dalam susu almond perlu dilakukan subtitusi dengan komoditas kacang lainnya yang memiliki kadar protein yang lebih tinggi. Umumnya, dalam pembuatan susu almond disubtitusi dengan kedelai untuk menambahkan kandungan protein di dalamnya. Kandungan mineral dalam susu almond yaitu kalsium sebesar 13,10 mg, fosfor sebesar 75,20 mg, natrium sebesar $6,38 \mathrm{mg}$, dan besi sebesar $1,40 \mathrm{mg}$. Perlu dilakukan penelitian lebih lanjut untuk mengetahui kandungan vitamin dan lainnya pada susu almond.

Prinsip dasar pembuatan susu almond hampir sama dengan pembuatan susu kedelai. Dilakukan perendaman selama 8-12 jam, pengupasan kulit, penghancuran, penyaringan. Susu almond dapat langsung disajikan tanpa melalui proses pemanasan atau dengan proses pemanasan $70^{\circ} \mathrm{C}$ selama beberapa menit. Masa penyimpanan susu almond yaitu sekitar 3-4 hari bila disimpan di kulkas. Susu almond memiliki tekstur encer, berwarna putih kekuningan, dan rasa tawar. Untuk menambah cita rasa pada susu almond dapat ditambahkan pemanis (Anonim, 2021). 


\section{Susu Gandum (Oat)}

Biji gandum memiliki kandungan gizi yang cukup tinggi, di antaranya karbohidrat $60-80 \%$, protein $10-20 \%$, lemak $2-2,5 \%$, mineral $4-4,5 \%$ dan sejumlah vitamin lainnya (Suarni, 2016). Umumnya, gandum sering diolah menjadi tepung, namun gandum juga dapat diolah menjadi susu yang kaya akan karbohidrat. Proses pembuatan susu gandum yaitu dilakukan dengan perendaman, penghancuran, penyaringan, dan pemanasan suhu rendah. Susu gandum memiliki warna putih kekuningan, tekstur encer, dan rasa tawar. Dapat ditambahkan gula, kurma, atau madu sebagai varian pemanis susu gandum.

Berdasarkan Tabel 2, jumlah kalori yang dihasilkan dalam susu gandum sebanyak 0,17 Kkal. Kadar protein dalam susu gandum memiliki rentang 2,5 - 5\%, cukup tinggi dibandingkan dengan susu sapi maupun susu nabati lainnya. Kadar lemak yang dihasilkan juga cukup tinggi yaitu berada di rentang 4,5-5\%. Kadar karbohidrat dalam susu gandum sebesar $19-29 \%$.

\section{Susu Kacang Hijau}

Kacang hijau merupakan varietas kacang-kacangan yang sangat umum dan mudah dijumpai. Kacang hijau mengandung protein sebanyak $20-25 \%$ (Meilla \& Husnul, 2015). Umumnya kacang hijau diolah sebagai bubur. Namun dewasa ini kacang hijau mulai didiversifikasi menjadi minuman. Susu kacang hijau adalah salah satu produk diversifitas kacang hijau yang memiliki gizi cukup tinggi.

Proses pembuatan susu kacang hijau hampir sama dengan susu nabati lainnya. Hanya saja ekstraksi kacang hijau tidak memerlukan perlakuan khusus seperti pada pembuatan susu kedelai untuk mengurangi bau langu karena rendahnya senyawa anti gizi (Andrestian \& Hatimah, 2015). Proses pasteurisasi susu kacang hijau dilakukan dengan suhu $65^{\circ} \mathrm{C}$ selama 30 menit. Susu kacang hijau memiliki warna yang berbeda yaitu hijau yang berasal dari warna asli kacang hijau, tekstur encer, dan hanya berlaku masa simpan satu hari (Andrestian \& Hatimah, 2015).

Kacang hijau mengandung kadar anti gizi yang tidak berarti sehingga tidak diperlukan perlakuan khusus pada saat pengolahan. Kadar asam fitat kacang hijau adalah $12 \mathrm{mg} / \mathrm{g}$, lebih rendah dari kedelai yaitu 36,4 mg/g (Andrestian \& Hatimah, 2015). Berdasarkan Tabel 2, kandungan air pada $100 \mathrm{ml}$ susu kacang hijau sebesar 
87,50\%. Kandungan air pada susu kacang hijau dapat berubah tergantung jumlah air yang ditambahkan. Kandungan protein dalam susu kacang hijau sebesar 1,57\% dan lemak $0,17 \%$. Kandungan lemak pada susu kacang hijau merupakan paling sedikit bila dibandingkan dengan susu nabati jenis lainnya dan susu sapi.

\section{Susu Kacang Mete}

Kacang mete berasal dari tanaman jambu mete (Anacardium occidentale L.). Proses pengolahan jambu mete terdiri atas pemilihan gelondong, penjemuran, pengupasan, penyangraian kacang mete berkulit ari, sortasi, pengeringan, dan pengemasan. Kacang mete merupakan buah dari tanaman jambu monyet yang menjadi produk yang paling penting dari pohon jambu monyet itu sendiri. Kacang mete biasanya dikonsumsi utuh, dipanggang, dikupas, dan diberi garam.

Kacang mete biasanya diolah dengan cara digoreng secara deep frying atau dijadikan sebagai makanan penunjang untuk makanan lain seperti coklat, kue, cookies, dan lainnya. Namun seiring dengan berjalannya waktu, produk kacang mete mulai didiversifikasi menjadi minuman susu. Proses pembuatan susu kacang mete yaitu dengan proses perendaman selama minimal 4 jam, lalu dihancurkan dan dilakukan penyaringan. Kemudian susu kacang mete dapat diminum langsung atau dilakukan proses pemanasan untuk membunuh mikroba bahaya yang tidak diinginkan. Karakteristik fisik yang dihasilkan yaitu tekstur encer dan berwarna kuning, serta menghasilkan bau kacang mete yang khas.

Jumlah kalori yang dihasilkan dalam $100 \mathrm{ml}$ susu kacang mete adalah 52 Kkal. Protein yang terkandung dalam susu kacang mete sebesar 1,31\%, lemak sebesar $3,16 \%$, karbohidrat sebesar 4,74\%, kalsium sebanyak 98,5 mg, asam lemak jenuh sebesar $0,44 \%$ dan kolesterol sebesar 0,44\%. Dikarenakan mengandung kolesterol, sebaiknya tidak disarankan untuk konsumsi secara rutin.

\section{Manfaat Susu Nabati}

Mayoritas susu nabati memiliki manfaat bagi kesehatan jantung dan stroke, hal ini dikarenakan kadar kolesterol yang minim bahkan tidak ada sama sekali. Susu kedelai memiliki kombinasi nutrisi yang seimbang, yang hampir mirip dengan susu sapi tetapi bebas gluten, kolesterol, dan laktosa (Riska, Ciptasari \& Nurrahman, 2020). 
Kandungan protein kedelai sekitar dua kali kandungan protein daging, yaitu sekitar $40 \%$ sedangkan kandungan protein daging sekitar 18\%. Kandungan protein yang tinggi ini sangat cocok dikonsumsi untuk masa pertumbuhan, terutama untuk sel otak serta pembentukan tulang. Susu kedelai juga cocok untuk mencegah penyakit stroke karena mengandung lesitin yang dapat menghancurkan timbunan kolesterol dalam darah dan jaringan tubuh lainnya sehingga dapat membebaskan tubuh dari serangan tekanan darah tinggi. Susu kedelai juga aman dikonsumsi oleh ibu hamil dan menyusui.

Susu almond dapat digunakan sebagai alternatif susu sapi bagi penderita intoleran laktosa. Tingginya asam oleat dan linoleat pada kacang almond sangat berperan baik dalam tubuh salah satunya menekan kolesterol sehingga baik untuk jantung serta meningkatkan laju aliran darah. Manfaat dari susu gandum yaitu bebas laktosa dan kacang sehingga aman dikonsumsi bagi penderita alergi susu sapi dan kacangkacangan, dan memiliki kandungan serat yang tinggi dapat membantu menurunkan kadar kolesterol. Namun yang harus diperhatikan adalah susu gandum mengandung gluten, sehingga bagi penderita alergi gluten dan penyakit celiac sebaiknya tidak mengkonsumsi susu ini (Puji, 2021). Susu kacang hijau mengandung bebas laktosa sehingga aman dikonsumsi oleh penderita intoleran laktosa. Minuman susu kacang hijau juga sangat baik dikonsumsi oleh berbagai kalangan usia.

Susu kacang mete memiliki manfaat bagi kesehatan tubuh. Susu kacang mete memiliki kandungan protein, kalsium, dan kalium yang rendah bila dibandingkan dengan susu sapi. Tetapi kandungan lemak tak jenuh, besi dan magnesium didalamnya sangat baik bagi kesehatan jantung dan mengatur tekanan darah tinggi. Susu kacang mete juga mengandung vitamin dan mineral yang baik untuk mengatur tekanan darah. Susu kacang mete juga mengandung antioksidan karotenoid, lutein dan zeaxhantin yang sangat baik bagi kesehatan mata. Susu kacang mete juga kaya akan vitamin $\mathrm{K}$ yang sangat penting untuk pembekuan darah dan membantu mencukupi kadar protein bagi tubuh. Susu kacang mete dapat membantu mengontrol gula darah sehingga cocok bagi penderita diabetes. Susu kacang mete juga baik untuk kesehatan kulit, memberikan efek anti kanker, meningkatkan kesehatan imun, dan mengobati anemia (Streit, 2019). 


\section{Penerimaan Konsumen Terhadap Susu Nabati}

Berdasarkan analisis pasar, konsumsi susu nabati terus meningkat. Pengembangan sensori dan kualitas susu nabati dapat menjadi faktor kunci dalam meningkatkan kesadaran produk. Namun dalam produk industri terdapat dua masalah yang diamati, yaitu rasa "nabati" atau tawar yang kuat karena adanya aktivitas enzim lipoksigenasi, serta rasa di mulut yang berbau arang yang disebabkan oleh partikel besar yang tidak larut (Aydar et al., 2020). Oleh karena itu, sudah cukup banyak industri yang melakukan improvisasi dan mengembangkan produk susu nabati dengan menambahkan pemanis serta melakukan proses penyaringan untuk menghilangkan kedua masalah tersebut. Perlu dilakukan pengembangan yang terus dilakukan untuk menambah cita rasa pada susu nabati tanpa menghilangkan manfaat dari susu.

\section{KESIMPULAN}

Berdasarkan studi literatur yang telah dilakukan, dapat disimpulkan bahwa susu nabati memiliki kandungan gizi yang hampir setara dengan kandungan gizi yang dimiliki oleh susu hewani. Mayoritas bahan nabati yang diperoleh berasal dari tanaman kacang-kacangan, namun ada juga yang diperoleh dari tanaman lain seperti gandum. Masing-masing varietas tanaman memiliki keunggulan kandungan gizi tersendiri sehingga dapat disesuaikan dengan nutrisi yang dibutuhkan oleh tubuh. Susu nabati cocok dikonsumsi oleh penderita intoleran laktosa dikarenakan kandungan laktosa hanya terdapat pada kelenjar ambing yang terdapat pada hewan. Proses pengolahan susu nabati yaitu sortasi, perendaman, penghancuran, penyaringan, dan pemanasan. Susu nabati umumnya diproduksi dengan proses pemanasan pasteurisasi dengan tujuan dapat membunuh mikroba patogen dan mikroba pembusuk lainnya tanpa merusak zat gizi yang terkandung di dalamnya. Karakteristik fisik pada susu nabati yaitu berwarna putih kekuningan (kecuali susu kacang hijau), bertekstur encer (tergantung volume air yang ditambahkan), rasa tawar dan memiliki bau yang khas. Daya awet pada susu nabati relatif rendah, yaitu 24 jam di suhu normal dan $3-4$ hari di suhu rendah. Untuk menambah cita rasa pada susu nabati terdapat alternatif dengan melakukan penambahan gula untuk menciptakan rasa manis pada susu.

Dikarenakan masing-masing varietas tanaman memiliki kandungan gizi yang berbeda, maka perlu diperhatikan tujuan dan kebutuhan nutrisi pada tubuh sebelum 
mulai mengkonsumsi susu nabati. Meski susu nabati memiliki kandungan gizi yang baik, namun ada kemungkinan terjadi efek tertentu pada kesehatan yang berasal dari bahan dasar nabati. Pada susu gandum, sebaiknya tidak dikonsumsi oleh penderita alergi gluten dan penderita penyakit celiac, dikarenakan mengandung gluten.

\section{DAFTAR PUSTAKA}

Aidah, S. N. (2020). Membongkar Rahasia Bisnis Susu Kedelai. Jogjakarta: Penerbit KBM Indonesia. [E-book]. Retrieved October 14, 2021, from https://books.google.com.sg/books

Alozie, Y.E., U. S. (2015). Nutritional and Sensory Properties of Almond (Prunus amygdalu Var. Dulcis) Seed Milk. World Journal of Dairy \& Food Sciences, 10(2), 117-121. https://doi.org/10.5829/idosi.wjdfs.2015.10.2.9622

Andrestian, M. D., \& Hatimah, H. (2015). Daya Simpan Susu Kacang Hijau (Phaseolus radiates L.) dengan Persentase Penambahan Sari Jahe Merah (Zingiber officinale var. Rubrum). Indonesian Jurnal of Human Nutrition, Juni 2015, 2(1), 38-47. http://dx.doi.org/10.21776/ub.ijhn.2015.002.01.4

Anonim. (2021). Resep Susu Kurma Almond, Bisa Jadi Ide Jualan. Retrieved Mei 29, 2021, from https://www.kompas.com/food/read/2021/02/03/220200475/resep-susu-kurmaalmond-bisa-jadi-ide-jualan?page=all

Aydar, E. F., Tutuncu, S., Ozcelik, B. (2020). Plant-based Milk Subtitutes: Bioactive Compounds, Conventional and Novel Processes, Bioavailability Studies, and Health Effects. Journal of Functional Foods, 70, 1-15. https://doi.org/10.1016/j.jff.2020.103975

Chalupa-Krebzdak, S., Long, C. J., Bohrer, B. M., (2018). Nutrient Density and Nutritional Value of Milk and Plant-Based Milk Alternatives. International Dairy Journal, 87, 84-92. https://doi.org/10.1016/j.idairyj.2018.07.018

Ciptasari, Riska, \& Nurrahman. (2020). Sifat Fisik, Sifat Organoleptik Dan Aktivitas Antioksidan Susu Bubuk Kedelai Hitam Berdasarkan Konsentrasi Tween 80. Jurnal Pangan Dan Gizi, 10(1), 45-59. https://doi.org/10.26714/jpg.10.1.2020.49-63

Damayanti, S. S., Murtini, E. S. (2018). Inovasi Susu Almond Dengan Subtitusi Sari Kecambah Kedelai Sebagai Sumber Protein Nabati. Jurnal Pangan dan Agroindustri, 6(3), 70-77. http://dx.doi.org/10.21776/ub.jpa.2018.006.03.8 
Deng, Y., Misselwitz, B., dkk (2015). Lactose Intolerance in Adults: Biological Mechanism $\begin{array}{llll}\text { and Dietary } & \text { Management. }\end{array}$ https://doi.org/10.3390/nu7095380

Erna, Silviana. (2019). Uji Organoleptik dan Kadar Protein Terhadap Susu Nabati Berbahan Baku Kacang Tanah (Arachis hypogaea) Dengan Penambahan Perisa Jeruk Manis (Citrus sinensis). Skripsi. Jurusan Pendidikan Matematika dan Ilmu Pengetahuan Alam. Universitas Sanata Dharma. Yogyakarta.

Facioni, M. S., Raspini, B., dkk (2020). Nutritional Management of Lactose Intolerance: the Importance of Diet and Food Labelling. Journal of Translational Medicine, 18(260), 260-269. https://doi.org//10.1186/s12967-020-02429-2

Gutierrez, T. J. (2020). Food Manufacturing for Babies and Children. [E-book]. Argentina: Springer. Retrieved October 14, 2021, from https://books.google.com.sg/books

Hasanah, N., Permana, I.D.G.M., Wisaniyasa, N.W. (2020). Pengaruh Perbandingan Almond dan Edamame Terhadap Karakteristik Susu Almond Edamame. Jurnal Itepa, 9(4), 448-457. https://doi.org/10.24843/itepa.2020.v09.i04.p09

Hoerudin, Mulyono, Edi. (2006). Perbaikan Proses Pengolahan Dan Mutu Kacang Mete: Studi Kasus di Madura, Jawa Timur. Jurnal J. Pascapanen, 3(2), 60-68. http://dx.doi.org/10.21082/jpasca.v3n2.2006.60-68

Istiqomah. (2014). Karakterisasi Mutu Susu Kedelai Baluran.Skripsi. Fakultas Teknologi Pertanian, Universitas Jember. Jember.

Kehinde, B. A, Panghal, A., Garg, M.K., Sharma, P., Chhikara, N. (2020). Vegetable Milk as Probiotic and Prebiotic Foods. Advance in Food and Nutrition Research, 94, 115-160. https://doi.org/10.1016/bs.afnr.2020.06.003

Larosta, J. T., Permana, D. G. M., Sugitha, I. M. (2019). Pengaruh Perbandingan Jagung Manis dan Edamame Terhadap Karakteritik Susu Jagung Manis Edamame. Jurnal Ilmu dan Teknologi Pangan, 8(4), 398-407. https://doi.org/10.24843/itepa.2019.v08.i04.p06

Muchtadi, T. R. (2019). Pengetahuan Bahan Pangan. Tangerang Selatan: Universitas Terbuka Muhami, Koeswardhani M Rosandari, T., Rulyenzi, R., Surono, I. S. Tampubolon, E. S., Dharmawati, A.A.A., Sukotjo, S., Syahril. (2017). Teknologi Pengolahan Pangan. Tangerang Selatan: Universitas Terbuka 
Pratita, N. (2012). Isolasi dan Identifikasi Kapang Mitoksin Pada Biji Kacang Tanah yang Dijual di Pasar Tradisional Pulo Brayan Medan. Tesis. Jurusan Biologi. Universitas Negeri Medan. Medan

Puji, A. (2021). Mengenal Nutrisi Susu Oat alias Susu Gandum yang Tak Kalah Sehat. Retrieved Mei 29, 2021, from https://hellosehat.com/nutrisi/fakta-gizi/nutrisi-susuoat-gandum/

Sentana, A., Trisnawati, C. Y., Jati, I. R. A. P. (2017). Identifikasi Sifat Fisikokimia Dan Organoleptik Susu Nabati Yang Diformulasikan Dengan Linear Programming. Jurnal Teknologi Pangan dan Gizi, 16(2), 47-51. https://doi.org/10.33508/jtpg.v16i2.1690

Streit, L. (2019). 10 Nutrition and Health Benefits of Cashew Milk. Artikel diambil Mei 30, 2021, from https://www.healthline.com/nutrition/cashew-milk-benefits

Suarni. (2016). Struktur dan Komposisi Biji dan Nutrisi Gandum. [E-book]. Pusat Penelitian dan Pengembangan Tanaman Pangan, Departemen Pertanian. Retrieved Mei 29, 2021, from http://balitsereal.litbang.pertanian.go.id/buku-gandum/

Triyono, A., Rahman, N., Andriana, Y. (2010). Pengaruh Proporsi Penambahan Air Pengekstraksi Dan Jumlah Bahan Penstabil Terhadap Karakteristik Susu Kacang Hijau (Phaseoulus radiatus, L.). Seminar Nasional Teknik Kimia "Kejuangan", Pengembangan Teknologi Kimia untuk Pengolahan Sumber Daya Alam Indonesia, Yogyakarta: UPN "Veteran” 